\title{
使用済み携帯電話およびパーソナルコンピュータに 含まれるレアメタル量の推計とそのインパクト評価
}

山末英嗣沼田健奥村英之石原慶一

京都大学エネルギー科学研究科

J. Japan Inst. Metals, Vol. 73, No. 3 (2009), pp. 198-204

(C) 2009 The Japan Institute of Metals

\section{Impact Evaluation of Rare Metals in Waste Mobile Phone and Personal Computer}

Eiji Yamasue, Takeshi Numata, Hideyuki Okumura and Keiichi N. Ishihara

Graduate School of Energy Science, Kyoto Universiry, Kyoto 606-8501

The amounts discarded laptop PC for home and business use from 1989-2025, desktop PC for home and business use from 1989-2025, mobile phone from 1991-2025 and PHS (handy phone system) from 1996-2025 have been estimated using population balance model. It is found that the discarded amounts of home PC are still increasing after 2010, while that increase rates in case of mobile phone and PHS are slight. The amounts of elements in all the discarded products have been estimated too using literatures and measured values. The impacts of the elements are discussed based on the comparison with domestic demands, the values weighted by total materials requirement (TMR) and the elemental concentration in the products normalized by that in crude ore.

(Received October 20, 2008; Accepted December 9, 2008)

Keywords: laptop PC(personal computer), desktop PC, mobile phone, rare metal, domestic demand, total materials requirement, elemental concentration

\section{1. 緒言}

大量生産・消費・廃棄に象徵されるフロー型社会に対する ものとしてストック型社会が提示されている．そのような中 で，「都市鉱山」と呼ばれる言葉が注目されている．都市鉱 山とは, 電子機器などの中に存在する大量の有用な資源 (レ アメタルなど)を鉱山に見立てたものである ${ }^{1)}$. 原田の推算 によると，日本国内の都市鉱山に含まれる金約 6800 トンと 世界の現有埋蔵量 42000 トンの約 $16 \%$ に抢よび，銀は $22 \%$ ，インジウム $61 \%$ ，スズ $11 \%$ ，タンタル $10 \%$ と世界 埋蔵量の一割を超える金属が多数あることが分かっている22.

しかし，これらは潜在的なストック量であり，これらのス トックからどのような割合で廃棄物として排出されるかを具 体的に知ることが効果的なリサイクルスキームを構築する上 で重要である。このような観点から, 著者らは 8 種類の家 電製品 (CRT テレビ, 液晶テレビ, プラズマテレビ, 洗濯 機, 冷蔵庫, エアコン, 掃除機, 電子レンジ)の廃棄量を推 定し，それらに含まれる金属元素の組成変化を考慮すること で，家電製品から潜在的に廃棄される金属元素量を評価し た ${ }^{3)}$. そして，それらの值を基に，国内需要に対する比率や 関与物質総量 (Total Materials Requirement, TMR)を用いて 各元素のインパクト評価することで，金だけでなく，ストロ ンチウムやバリウムのインパクトが高く, これらの元素のリ サイクルにも注目すべきであることを示した。
一方，ノートパソコンや携帯電話といった小型電子機器は 個々の重量は数 $10 \mathrm{~g}$ 数 $\mathrm{kg}$ と比較的軽量であるが, 家電製 品が 1 世帯に 1 台程度であるのに対し, 近年, これらは 1 人に複数台保有されるほどに普及している.さらに，これら の製品には小型化・高性能化のために家電製品に比べ多種類 のレアメタルが高濃度で使用されていることが多い。

日本では, 2000 年 6 月に循環型社会形成推進基本法が施 行され, 循環型社会の形成について基本原則が定められた。 そこでは，2001 年度の循環利用率 $9.9 \%$ を 2010 年には約 14\%にすることを目標としている. また，個別製品の特性 に応じた規制として, 家電リサイクル法など, 各種リサイク ル法が施行されている.さらに 2003 年 10 月にはパソコン リサイクル法が施行され, パソコンのリサイクルが本格的に 始められた．例として法人から排出されるデスクトップパソ コン，ノートパソコンの資源再利用率はそれぞれ約 80\%, 60\%と高い值になっている4). 携帯電話やPHSについて は, リサイクル法は施行されていないものの, 一部リサイク ルが行われている.しかし，金，銀，銅などは比較的積極的 にリサイクルを進める動きがあるものの, その他多くのレア メタルについてはリサイクルがほとんど行われていないのが 現状である.リサイクルが進まない原因には多くが考えられ るが，それらの製品中にどの元素がどのくらい含まれてお り，それがどの程度排出されているか？というデータがない ことも要因の一つと考えられる.

近年, 多くの家電製品や携帯電話・パソコンなどの組成は 
多くの研究者によって比較的精力的に調査されており，また その廃棄台数も調査されている. 例えば, 中島らは携帯電話 の組成を詳細に調査し5), また小口らは 23 品目の製品につ いて, 2008 年までの廃棄台数の予測を行い, パソコン, 携 帯電話については 2003 年度以降の出荷台数を一定として予 測を行っている6)。 また, 上述のように, 日本全体における 種々の元素のストック量は原田らにより詳細に提示されてい るが，そのストックからどの程度廃棄物として排出されてい るかについての詳細なデータは, 我々が調べる限りほとんど 見られない.

以上より, 本研究の目的は, 使用済み小型電子機器台数を より詳細に推計し，それらに含まれる元素量の持つインパク トを種々の手法で評価することで, どの元素のリサイクルに より注目すべきかについて提示することを目的とする。

\section{2. 研 究 手 順}

\section{1 廃棄台数の推算方法}

本研究では, ノートパソコン, デスクトップパソコン, 携 帯電話, PHS を対象とし, それらの使用済久製品中に含ま れる金属量の推算を行った.ノートパソコン, デスクトップ パソコンについては, 家庭用, 事業用に分けて計算を行っ た、また，本研究では使用済久台数の予測を行って扣り，使 用済み後も保有される退蔵分と破棄される製品については区 別していない。したがって, 正確には潜在的使用済み台数と 呼称すべきであるが，本稿では使用済み台数と呼ぶことにす る.

著者らが使用済久家電製品台数を推計した際3)にはポピュ レーションバランスモデル7-8)

$$
P_{\mathrm{i}, t}-W_{\mathrm{i}, t}=N_{\mathrm{i}, t}-N_{\mathrm{i}, t-1}
$$

を用いており, 本研究の推計においても同じモデルを使用し た.ここで $P_{\mathrm{i}, t}$ はある製品 $\mathrm{i} の t$ 年度における国内出荷台数, $W_{\mathrm{i}, t}$ は使用済み台数, $N_{\mathrm{i}, t}$ および $N_{\mathrm{i}, t-1}$ はそれぞれ $t$ 年度, $(t-1)$ 年度に抢ける国内保有台数である.

計算に必要な将来の保有台数は, 一部の例外を除いて式 ( 2 ) で表されるロジスティック関数を用いて推定した.

$$
N_{\mathrm{t}}=\frac{N_{\max }}{1+A \exp \left(-B\left(t-t_{0}\right)\right)}
$$

ここで, $N_{\max }$ は最大保有台数, $t$ は年度, $t_{0}$ は基準年度, $A$, $B$ は定数である. 本研究では $N_{\max }, A, B$ をパラメータと し, 既存の保有台数データに最小二乗フィッティングするこ とでパラメータ值を決定した。

各製品の使用済み台数は出荷台数から寿命関数を用いて推 計した. 寿命関数としては式 (3)

$$
F_{\mathrm{t}}(y)=1-\exp \left[-\left(\frac{y}{\bar{y}}\right)^{b} \times\left\{\Gamma\left(1+\frac{1}{b}\right)\right\}^{b}\right]
$$

で表されるワイブル分布関数を用いた．ここで $F_{t}(y)$ は $(t-$ $y)$ 年度に出荷された製品が $t$ 年度までに廃棄される累積の確 率を示している. $\bar{y}$ は平均使用年数である.さらに $\Gamma$ はガン マ関数， $b$ は使用年数分布の幅を示すパラメータである.

\begin{tabular}{|c|c|c|}
\hline & $\bar{y}$ & $b$ \\
\hline Home laptop $\mathrm{PC}^{9)}$ & 9.1 & 3.1 \\
\hline Home desktop $\mathrm{PC}^{9)}$ & 8.4 & 5.4 \\
\hline Business laptop PC ${ }^{10)}$ & 5.0 & 3.9 \\
\hline Business desktop $\mathrm{PC}^{10}$ & 5.0 & 3.9 \\
\hline Mobile Phone $e^{6,11)}$ & 1.5 & 3.1 \\
\hline PHS & 2.9 & 3.1 \\
\hline
\end{tabular}

Table 1 に本研究で用いた $\bar{y} と b$ のパラメータ6,9-11)を示す.
Table 1 Parameter of $\bar{y}$ and $\mathrm{b}$ for Weibull distribution function.

\section{2 使用データと仮定}

各製品の出荷台数と保有台数について説明する.

パソコン全体の出荷台数データは 1990 年から 2005 年ま でしか存在しなかった ${ }^{9,12)}$. そこでパソコンが発売された 1979 年から 1990 年まで出荷台数が線形に増加すると仮定 した. また，ノートパソコンやデスクトップパソコン個別の 出荷台数は 1996 年以降しか存在しなかった．とこでノート パソコンの出荷台数データは 1996 から 2005 年は JEITA の データを用いた ${ }^{12)}$. 1995 年以前については, パソコン全体 の出荷台数に占めるノートパソコンの割合が，ノートパソコ ンが発売された 1989 年から 1996 年まで線形に増加すると 仮定して求めた. デスクトップパソコンについては, パソコ ン全体の出荷台数からノートパソコンの出荷台数を除いたも のを用いた.さらに家庭用, 事業用の出荷台数については, 1995 年から 2004 年まで家庭用出荷割合のデータが含まれ ていたため, 1994 年以前については 1995 年の割合, 2004 年以降については 2004 年の割合を用いた ${ }^{12)}$.

携帯電話とPHS の出荷台数データは生産動態統計調査の データを用いた ${ }^{13)}$. 出荷台数は携帯電話, PHS 共に 1999 年以降のデータが, 生産台数については携帯電話が 1992 年 以降, PHS は 1997 年以降のデータが存在する.ここで出荷 台数データと生産台数データでほとんど違いが見られなかっ たため, 本研究では出荷台数データが存在しない部分は生産 台数データを用いた. さらに, 携帯電話の 1991 年, PHS の 1996 年以前については, 製品が発売された年からデータが 存在する年まで線形に出荷台数が増加すると仮定した.

携帯電話の保有台数は携帯電話の契約者数 ${ }^{14)}$ と等しいと 考え, 携帯電話の契約者数から回帰分析により, 上述のロジ スティック関数のパラメータを設定した. PHSの保有台数 はPHSの契約者数 ${ }^{14)}$ と等しいと仮定した. PHS の保有台数 は一度増加し，その後減少し，近年ではまた増加しつつある ため, ロジスティック関数に当てはめることができない. PHS の保有台数データは 1996 年 9 月から 2007 年 5 月分ま で存在する．そこで 1996 年以前に関しては，PHS が発売さ れた年から 1996 年まで線形に保有台数が増加すると仮定し た.さらにPHSの将来の保有台数は 2007 年 5 月時点での 保有台数と同等とした.

\section{3 組成分析}

本研究では, 各製品の組成を文献值5,15-17) を用いて算出し た. また, 対象とした電子機器中に確実に含まれると思われ るにもかかわらず, 記載がなかった元素種 $(\mathrm{Ti}, \mathrm{Nd}, \mathrm{Ta}) に つ$ 
Table 2 The amounts of elements in the products.

\begin{tabular}{lcccl}
\hline & Laptop & Desktop & Mobile phone & PHS \\
\hline $\mathrm{Mg}(\mathrm{g})$ & - & - & 3.37 & \\
$\mathrm{Al}(\mathrm{g})$ & 241 & 529 & 0.34 & \\
$\mathrm{Cr}(\mathrm{g})$ & 0.93 & 2.36 & 0.62 & 0.06 \\
$\mathrm{Mn}(\mathrm{g})$ & - & - & 0.04 & 0.04 \\
$\mathrm{Fe}(\mathrm{g})$ & 231 & 4928 & 6.66 & \\
$\mathrm{Ni}(\mathrm{g})$ & 4.30 & 10.92 & 0.74 & 0.68 \\
$\mathrm{Cu}(\mathrm{g})$ & 38.04 & 96.65 & 11.78 & 7.67 \\
$\mathrm{Zn}(\mathrm{g})$ & - & - & 0.04 & \\
$\mathrm{Ga}(\mathrm{g})$ & - & - & 0.04 & 0.03 \\
$\mathrm{Mo}(\mathrm{g})$ & 0.04 & 0.11 & & \\
$\mathrm{Pd}(\mathrm{g})$ & 0.06 & 0.15 & 0.004 & 0.01 \\
$\mathrm{Ag}(\mathrm{g})$ & 0.12 & 0.30 & 0.01 & 0.004 \\
$\mathrm{In}(\mathrm{g})$ & - & 1.27 & 0.01 & 0.001 \\
$\mathrm{Sn}(\mathrm{g})$ & 15 & 37 & 1.78 & 1.78 \\
$\mathrm{~W}(\mathrm{~g})$ & - & - & 0.55 & 1.09 \\
$\mathrm{Pt}(\mathrm{g})$ & 0.006 & 0.003 & 0.002 & 0.002 \\
$\mathrm{Au}(\mathrm{g})$ & 0.05 & 0.14 & 0.01 & 0.02 \\
$\mathrm{~Pb}(\mathrm{~g})$ & 7.71 & 19.6 & 0.01 & 0.01 \\
\hline $\mathrm{Ti}(\mathrm{g})$ & 0.18 & - & 0.01 & 0.01 \\
$\mathrm{Nd}(\mathrm{g})$ & 0.62 & 2.49 & 0.01 & 0.01 \\
$\mathrm{Ta}(\mathrm{g})$ & 0.31 & - & 0.04 & 0.003 \\
\hline
\end{tabular}

いては，それぞれセラミックコンデンサ，パソコンの HDD 中の磁石あるいは携帯電話, PHS 中のバイブレーション モータ, タンタルコンデンサを取り出し, 粉砕した後, エネ ルギー分散型 X 線分析装置 $(\mathrm{EDX})$ を用いて実測した。ノー トパソコン，携帯電話については 3 台の平均値を用い，デ スクトップパソコン, PHSについては 1 台を分析し，代表 值とした。本研究で用いた各金属の組成を Table 2 に示す.

\section{3. 推 算 結 果}

\section{1 廃棄台数の推算結果}

Fig. 1 4 にノート PC, デスクトップ PC の家庭用および 事業用の出荷台数抢よび使用済反台数予測，Fig. 5 6 に携 帯電話抢よびPHS の出荷台数抢よび使用済反台数予測結果 を示す．図から，全ての製品に抢いて，2000 年前後の出荷 台数は大きく増加しているが，近年は微増傾向にあることが わかった。これは, 本研究で対象としている 4 種類の電子 機器は, 日本に打いては普及台数がほぼ飽和状態に達してい ることを反映している結果と考えられる。一方, 廃棄台数は 家庭用 PC では 2010 年以降もしばらく増加が見られるが, 業務用 PC の増加は小さく, 携帯電話と PHS では微増程度 である。これは，携帯電話や PHS が使用済みになるまでの 年数が短いため, 出荷台数の低下の影響を受けやすいためで ある.

ここで, 各製品の 2006 年度の廃棄台数予測と実際の回収 台数との比較を行う. $\mathrm{PC}$ の回収台数はパソコン $3 \mathrm{R}$ 推進セ ンター4), 携帯電話はモバイル・リサイクル・ネットワー ク18)のデータを用いた。 その結果, 家庭系ノート PCで $5 \%$, 事業系ノート PC で 6\%, 家庭系デスクトップ PC で 9\%, 事業系デスクトップ PCで $8 \%$, 携帯電話で $15 \%$ とい う低い值が得られた。家庭用 PCについては, 使用済反製品 の家庭内への退蔵か中古品として売却・譲渡が多いことを示 唆している.ノートPC の回收率がデスクトップ PC より低 いのは，ノート PC が小型であるために家庭内に退蔵しやす

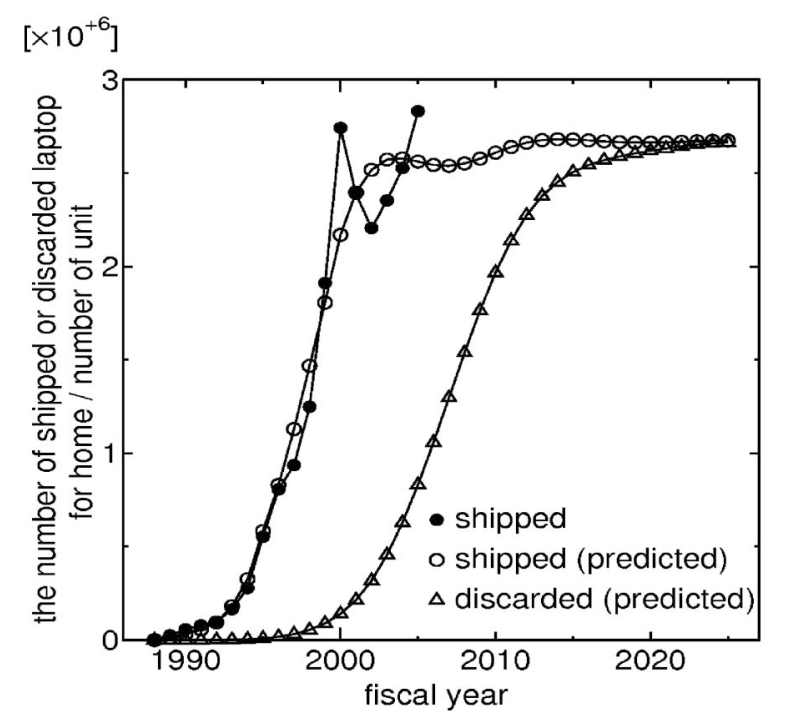

Fig. 1 The estimated amounts of shipped and discarded number of home laptop PC.

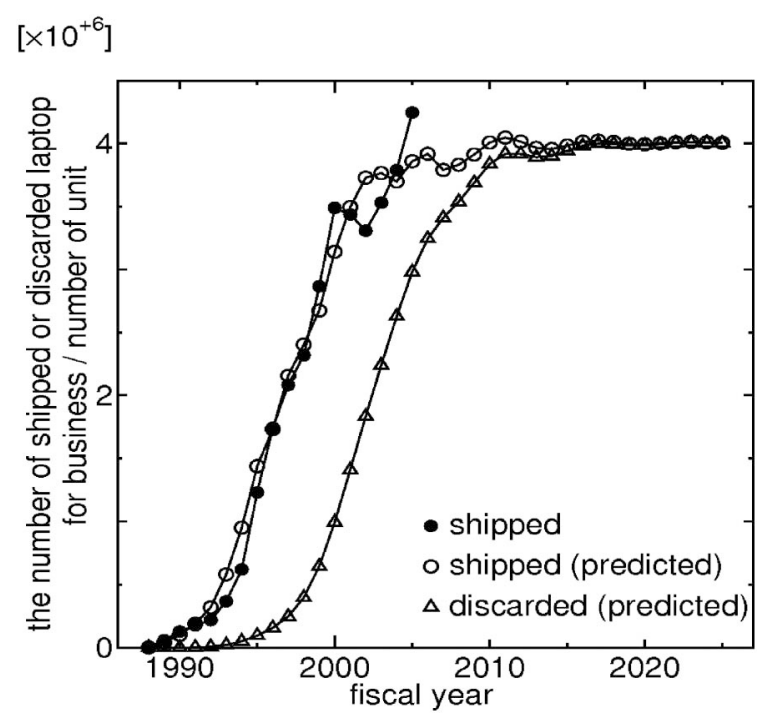

Fig. 2 The estimated amounts of shipped and discarded number of business laptop PC.

いことが原因と考えられる. 事業用パソコンではレンタルや リースしたパソコンも用いられているため, 回収率が低いと 考えられる. 携帯電話の回収率が PCより高いのは, 携帯電 話を買い換える際にそれまでに使用していた携帯を返却する ことを店頭で求められることが理由と考えられるが，これは 義務ではないため, 回収率は決して高くない, 今後, 資源有 効利用促進法の効力の評価を行う上で, 回収率の向上は大き な課題になると考えられる.

\section{2 使用済み電子機器に含まれる元素の推算結果}

Fig. 7〜10 に本研究で対象とした使用済久製品中に含まれ る元素量の推算値を示す. 本研究では, 各電子機器の組成の 時系列的な変化については考慮せず, 組成分析の対象とした 製品は $2000 \sim 2007$ 年製であるため, 推算は 2000～2015 年 の範囲で行った，図から分かるように，全ての元素で使用済 久電子機器中に含まれる量は増加傾向にあることが分かる. 
$\left[\times 10^{+6}\right]$

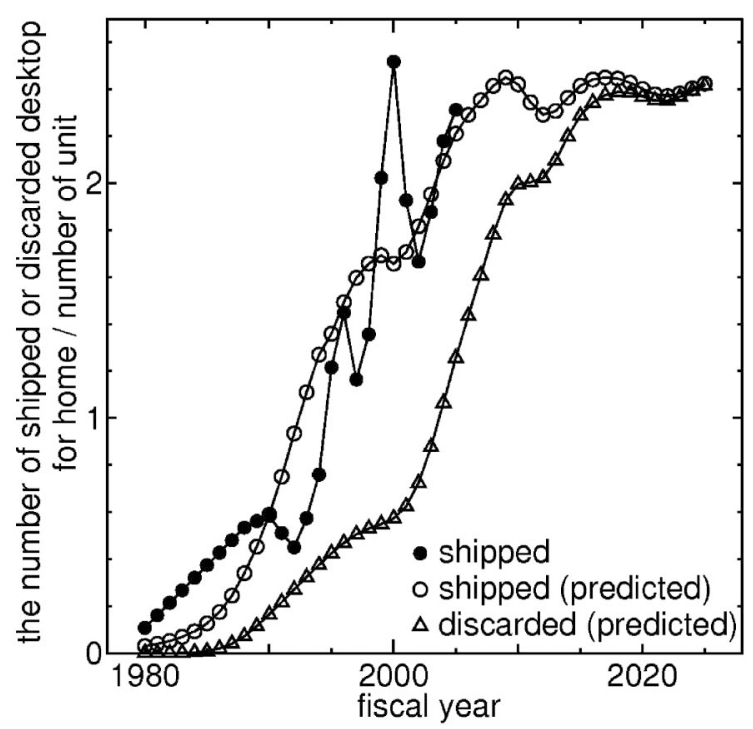

Fig. 3 The estimated amounts of shipped and discarded number of home desktop PC.

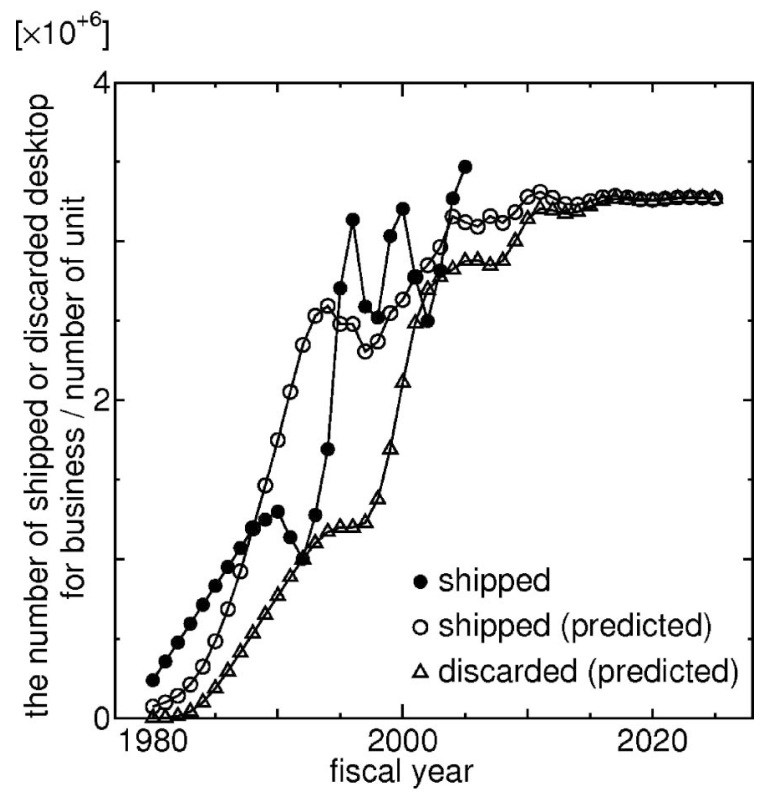

Fig. 4 The estimated amounts of shipped and discarded number of business desktop PC.

\section{4. 考察}

\section{1 国内需要を用いたインパクト評価}

2007 年度に打ける使用済久製品中の元素量と, 独立行政 法人石油天然ガス・金属鉱物資源機構 (JOGMEC)の資料に 基づく各元素の国内需要量 ${ }^{19)}$ を比較すると, 高いもので $\mathrm{Pd}$ が $3.1 \%$, Ga が 1.4\%, Sn が 1.4\%, In が 1.1\%, Ta が $0.8 \%, \mathrm{Au}$ が $0.7 \%, \mathrm{~W}, \mathrm{Pt}, \mathrm{Nd}$ が $0.4 \%$ であった。この值 は絶対的には大きいものではないが，それでも $\mathrm{Au}, \mathrm{Ag}, \mathrm{Cu}$ が実際にはリサイクルが進められている現状を考えると, Ga や Inのリサイクルが行われていないのは懸念すべき事項 である，また， 8 種類 (CRT テレビ, 液晶テレビ, プラズマ $\left[\times 10^{+7}\right]$

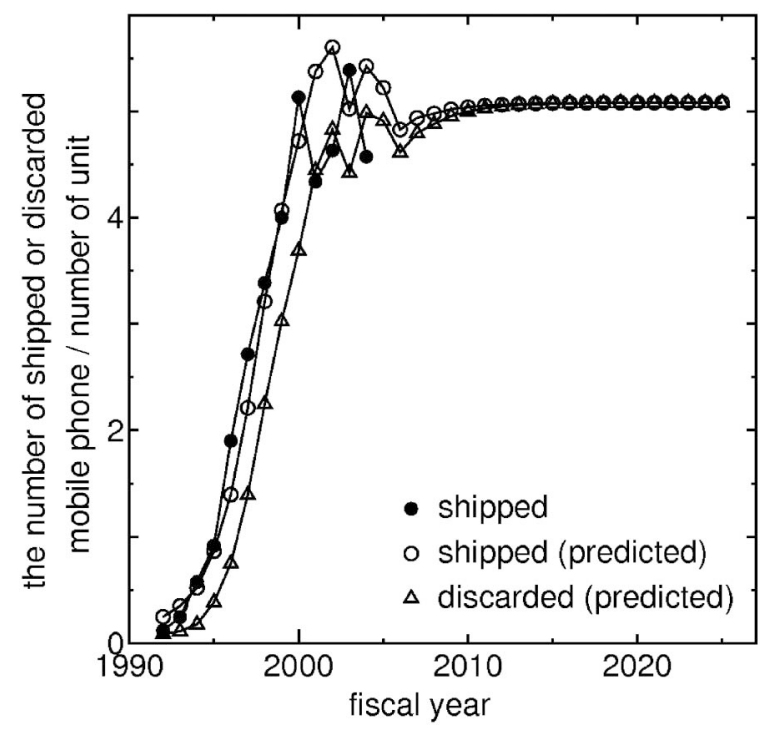

Fig. 5 The estimated amounts of shipped and discarded number of mobile phone.

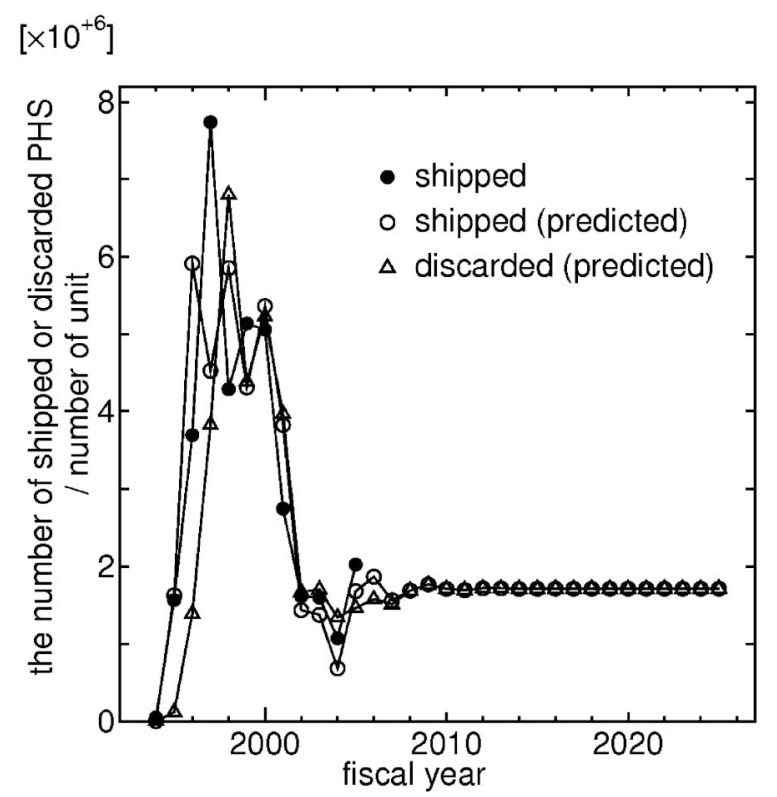

Fig. 6 The estimated amounts of shipped and discarded number of mobile PHS.

テレビ，冷蔵庫，洗濯機，エアコン，電子レンジ，掃除機） の使用済久家電製品中の元素量に対しても同様の分析を行う と3), 大きいもので $\mathrm{Sn}$ が $4.4 \%$, In が $0.6 \sim 2 \%, \mathrm{Ag}$ が $1.6 \%, \mathrm{Au}$ が $0.4 \%$ であった. 本研究で対象としている 4 種 類の使用済及電子機器の重量約 92.7 万トンが上述の家電製 品(1300 万トン)の $7.1 \%$ に過ぎないことを考慮すると, 如 何に高濃度のレアメタルが 4 種類の使用済久電子機器に含 まれているかを理解できる。 また， Nd, W, Ga などは一般 的には家電製品には用いられない元素であるため, 携帯電話 や PC からのこれらの元素の回収はより重要になると考えら れる。 


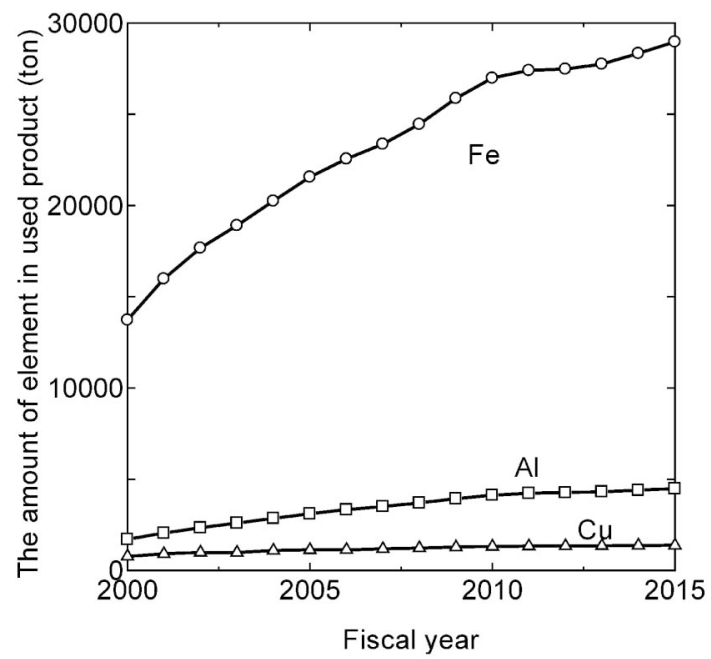

Fig. 7 The estimated amounts of $\mathrm{Fe}, \mathrm{Al}$ and $\mathrm{Cu}$ in discarded laptop PC, desktop PC, mobile phone and PHS.

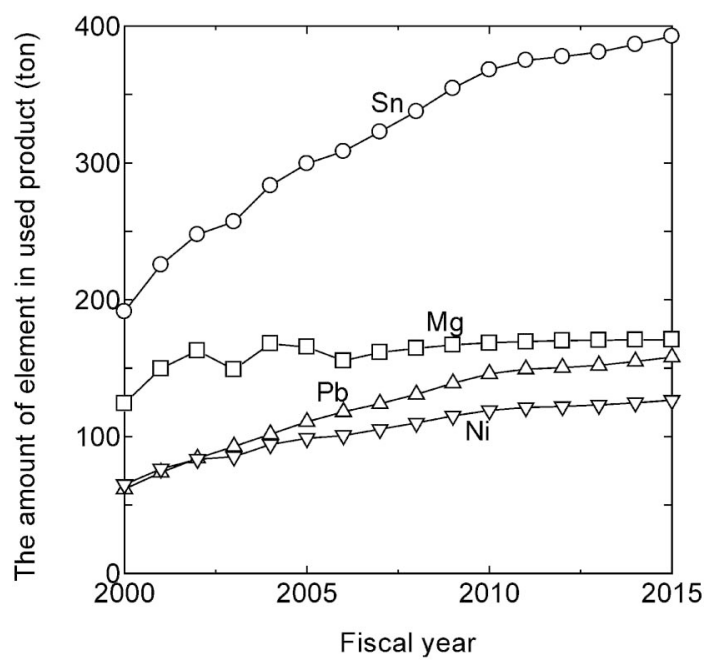

Fig. 8 The estimated amounts of $\mathrm{Mg}, \mathrm{Ni}, \mathrm{Pb}$ and $\mathrm{Sn}$ in discarded laptop PC, desktop PC, mobile phone and PHS.

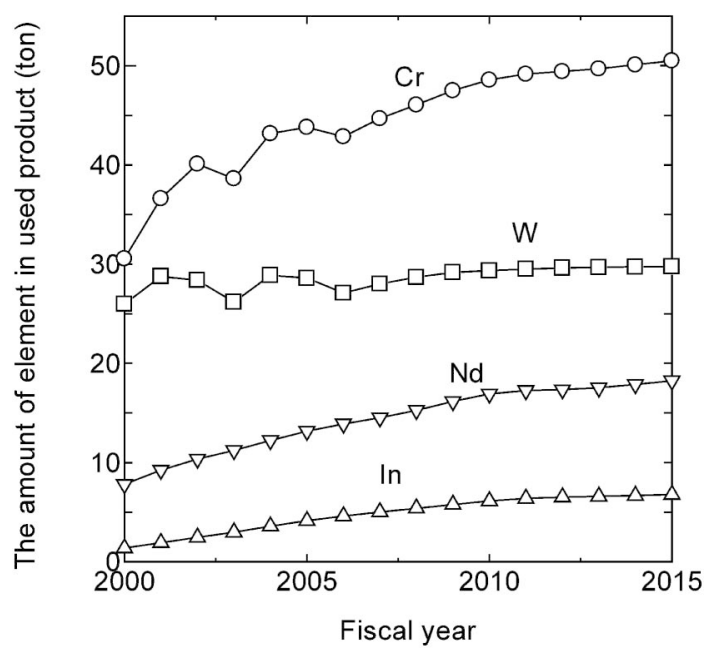

Fig. 9 The estimated amounts of $\mathrm{Cr}$, In, Nd and $\mathrm{W}$ in discarded laptop PC, desktop PC, mobile phone and PHS.

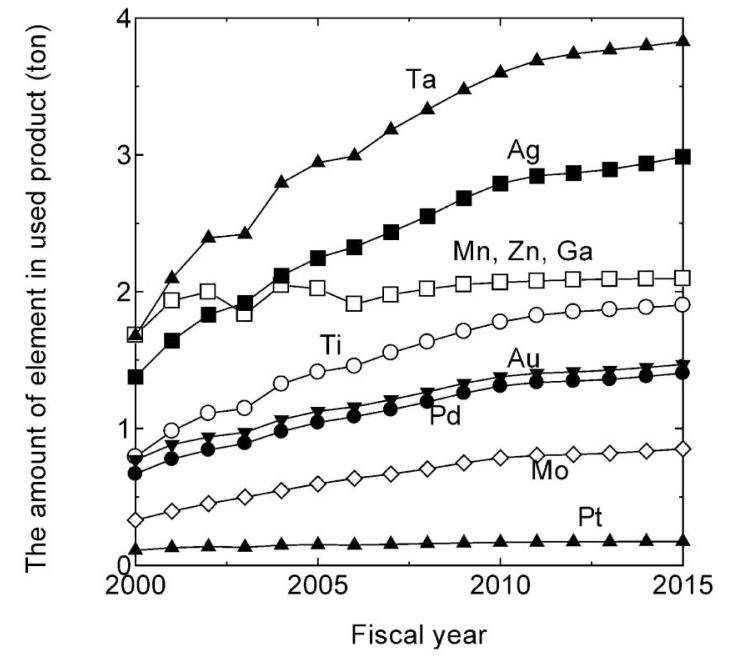

Fig. 10 The estimated amounts of Ag, Au, Ga, Mn, Mo, Pd, $\mathrm{Pt}$, Ta, Ti and $\mathrm{Zn}$ in discarded laptop PC, desktop PC, mobile phone and PHS.

\subsection{TMR を用いたインパクト評価}

本節では，使用済み電子機器に含まれる元素量に対して， 粗鉱からある元素を得るまでの物質集約度を示す指標の一つ である関与物質総量 (Total Materials Requirement, TMR)を 重み付け因子として用いた評価を行う。TMR と環境負荷の 直接的な関連性は証明されていないが，TMRでは隠れたフ ローとして動かされるずりや剥土の寄与が考慮されているた め, 地球環境に対して与えた攪乱量を評価することが可能で ある. TMRの值は, 原田らの報告值を用いた ${ }^{20)}$.

Fig. 11 は， 2010 年度に使用済みとなった 4 種類の電子機 器に含まれる元素量をTMR で重み付けした結果である.な お，図中には，3.2 節で示した 8 種類の使用済久家電製品に 含まれる元素を同じくTMR で重久付けしたものも比較のた めに示している. 図から分かるように, 使用済久携帯電話 · $\mathrm{PC}$ に含まれる元素のうち, $\mathrm{Au}, \mathrm{Pd}$ が高い值を示し, $\mathrm{Cu}$, $\mathrm{Fe}, \mathrm{Al}, \mathrm{Pt}, \mathrm{Nd}$ が続いている. 全ての重み付けされた数值を 足すと約 380 万トンとなる。この值は，Fe(TMRは 8 ton/ ton) 換算で 48 万トンに相当し, これは日本における年間粗 鋼生産量の約 $0.4 \%$ にも值する. わずか 4 種類の小型電子機 器に含まれる元素が, このような大量の鉄と同程度の攪乱を 地球環境に対して与えていることに注目すべきである.

家電製品の場合と比較すると, 総重量で勝る家電製品がほ とんどの元素で使用済久携帯電話 · PCの場合より大きな值

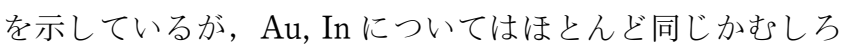
大きな值を示していることに注意しなければならない。 $\mathrm{Au}$, In は枯渴が強く懸念されている元素であり, 家電製品だけ でなく携帯電話や PC からのこれらの元素の回収にも目を向 ける必要がある. また, Pt や Pdのように PC や携帯電話の みに使われている元素にも注意しなければならない。使用済 み家電製品の場合，全ての元素について TMR で重み付けさ れた数值の合計値は約 4200 万トンとなり, 使用済久携帯電 話·PC の場合の約 11 倍に相当する. 大きな差は家電製品 の重量が携帯電話や PC に比べて大きいことが原因である. そこで, 両者からベースメタルである $\mathrm{Fe}, \mathrm{Al}, \mathrm{Cu}$ の值を除 
The amount of element weighted by TMR (ton)

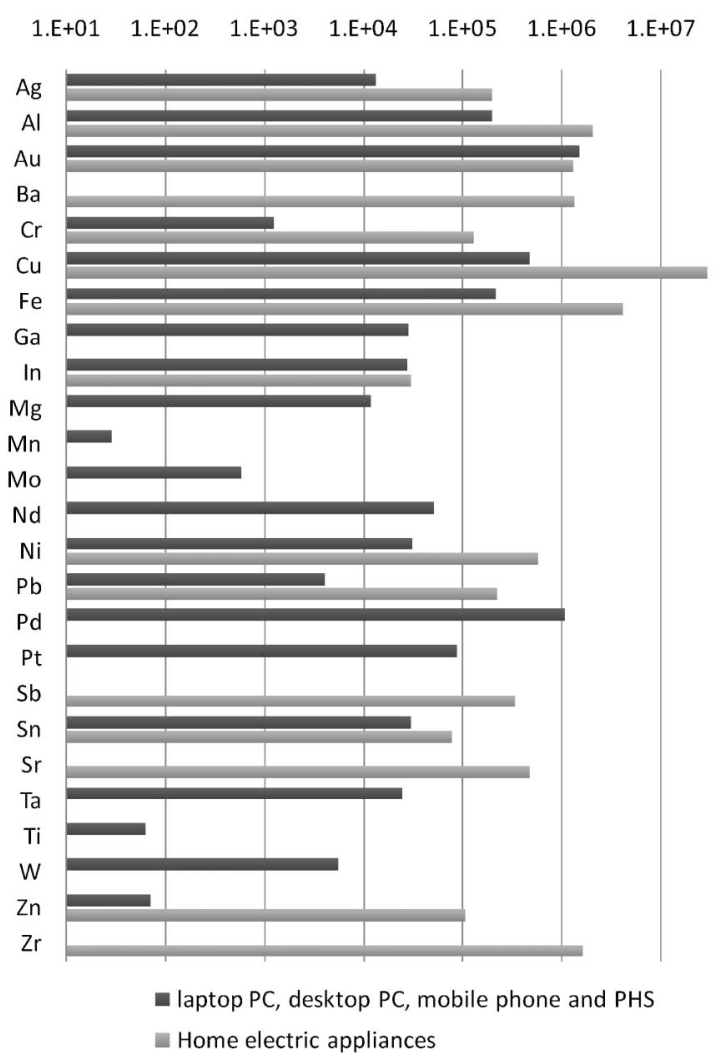

Fig. 11 The amount of element in laptop PC, desktop PC, mobile phone and PHS weighted by TMR compared with the case of home electric appliances (CRT, LCD, Plasma TV, air conditioner, refrigerator, washing machine, vacuum cleaner, microwave oven).

外して合計值を再計算すると，使用済久家電製品で約 620 万トン，使用済久携帯電話・PCで約 290 万トンとその差が 2 倍程度となる。これは使用済久携帯電話・PCに含まれる レアメタルの持つインパクトの大きさを示唆する結果であ る.この点からも, 使用済久携帯電話・PC からのレアメタ ル, 特に $\mathrm{Au}$, Inの積極的なリサイクルが求められる.

\section{3 リサイクル促進のための課題}

携帯電話や PC にはレアメタルが大量に入っており，それ らを効果的にリサイクルする必要性があることが国内需要と の比較や，TMRによる重み付けを行う分析から示した．た だし，それらに含まれるレアメタルを全てリサイクルすれば よい訳ではない。リサイクルの優先性を決めるため, 自然鉱 石とこれらの製品を比較することは一つの方針と考えられ る.このような観点から, 筆者は元素濃度を比較のための指 標とし，家電製品に含まれるレアメタルのリサイクラビリテ ィを評価してきた ${ }^{21)}$.

Fig. 12 はノート PC, デスクトップ PC, 携帯電話, PHS のそれぞれを単位都市鉱石と考え, それぞれに含まれる元素 濃度を比較したものである.ただ，自然鉱石に含まれる元 素濃度で規格化しており, 以降この指標を元素濃度比と呼称 する. 元素濃度比が 1 より大きい場合, 自然鉱石の元素濃 度より都市鉱石の元素濃度が高いことを意味する．図から分 かるように，全ての製品について， $\mathrm{Au}, \mathrm{Ag}, \mathrm{Pd}$ が粗鉱より
Elemental concentration normarized by that in crude ore

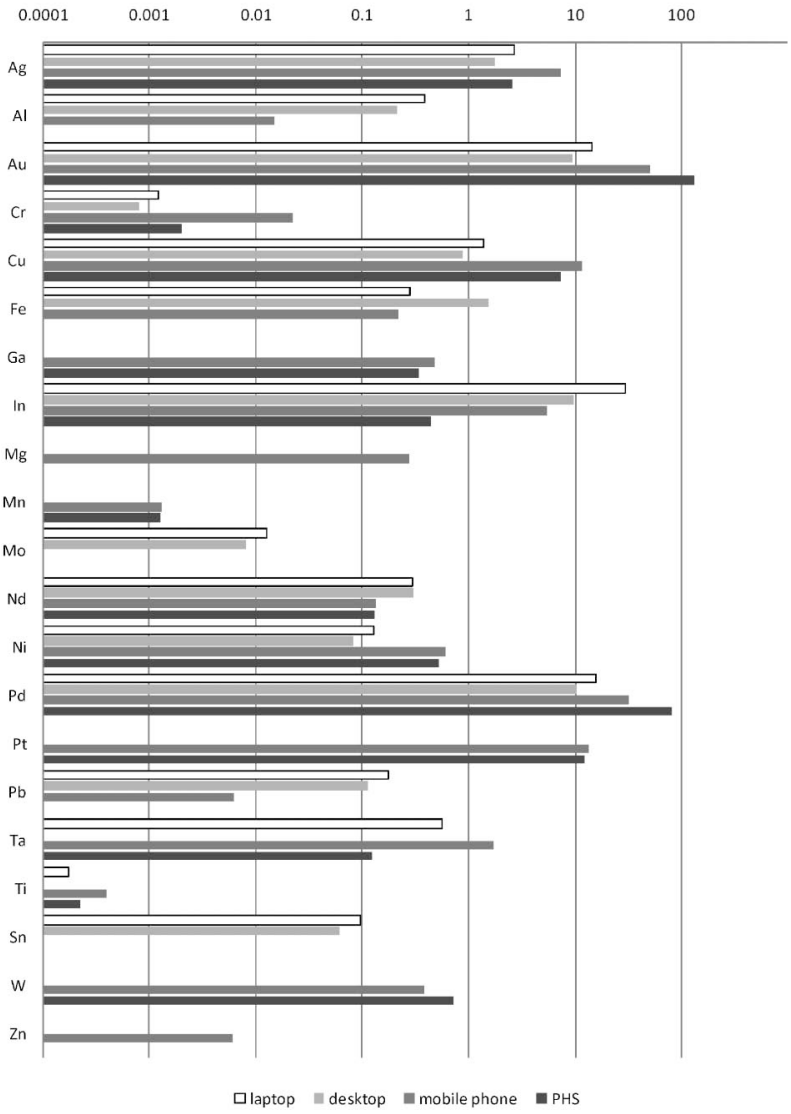

Fig. 12 The ratio of elemental concentration in each product normalized by that in crude ore.

も高い濃度を示し，Pt, In, Cu はそれらに準じて高い濃度を 示している. 事実, 上述の元素のうち, In を除いて使用済 久電子機器から極力リサイクルする努力がされている。一 方，携帯電話のバイブレーターに含まれる W P PCのハー ドディスクに使用される磁石中の $\mathrm{Nd}$ の元素濃度比は 1 より 小さく, 実際にリサイクルされていない。実際には, リサイ クラビリティは環境問題などを考えて判断されているわけで はなく，リサイクル業者にとってコスト的に見合うためであ るが，実際にリサイクルされている元素とされていない元素 を，このような簡単な指標である程度説明できることは興味 深い事実である。

元素濃度比を用いた評価法の問題点として，これらの定義 では鉱山から元素を抽出・製錬するためのエネルギーを評価 できないことが挙げられる，そのため，例えば，都市鉱石 (使用済久電子機器) に含まれる金属 $\mathrm{Al}$ の品位と天然の $\mathrm{Al}$ 鉱石(ボーキサイト)の品位を単純に比較できないという問題 も発生する. そのため, 元素濃度比が 1 より小さい值を示 した Fe や $\mathrm{Al}$ も実際にはリサイクルしようと努力されてい る. 一方で In の元素濃度比が 1 より大きいにもかかわらず リサイクルされていないのは, 効果的なリサイクル方法が開 発されていないためである.

さらに，都市鉱石の有する大きな問題点として，個々の製 品中の元素濃度は自然鉱石と比較して高い一方で，それらは 各家庭や企業内，すなわち日本全土に希薄に存在していると 
いることに注意しなければならない。日本全体を一つの鉱山 と見たとき，実際には都市鉱山の品位はそれほど高くない. この意味するところは，偏在して高品位である都市鉱石を如 何に効率的に消費者からリサイクルプラントまで輸送するか が一つの鍵になるという点である。 また，使用済久電子機器 の効果的な分離・解体方法についても検討しなければならな い.しかし，元素濃度比を用いた手法では，これらの課題を 評価できないことは自明である. 今後, 都市鉱石の有効なリ サイクル，すなわちリサイクラビリティを評価するために は，元素濃度比の概念をべースとして抽出や製錬に要するエ ネルギーの影響も加味した評価方法を開発することが重要に なると考えられる。

\section{5. 結}

\section{論}

本研究では，使用済みノート PC 台数(家庭用，業務用)を 1989 2025 年まで，デスクトップ PC (家庭用，業務用)に ついては 1979～2025 年まで，携帯電話については 1991〜 2025 年末で, PHS については 1996～2025 年まで推計し た. 全ての製品において, 2000 年前後の出荷台数は大きく 増加しているが, 近年はその微増傾向にあることがわかっ た. 廃棄台数は家庭用 PCでは 2010 年以降もしばらく増加 が見られるが，業務用 $\mathrm{PC}$ の増加は小さく，携帯電話と PHS では微増程度であることがわかった。 また，それらに 含まれる元素量を文献值と実測值から 2000～2015 年の範囲 で推算した。その結果, 全ての元素で使用済み PC・携帯電 話に含まれる量は増加傾向にあることが分かった。

使用済み $\mathrm{PC}$ ・携帯電話に含まれる各元素について国内需 要量と比較した結果, $\mathrm{Pd}$ が $3.1 \%, \mathrm{Ga}$ が $1.4 \%, \mathrm{Sn}$ が $1.4 \%$, In が $1.1 \%$, Ta が $0.8 \%$, Au が $0.7 \%$, W, Pt, Nd が $0.4 \%$ と比較的高いインパクトを示すことが分かった。 た TMRで重み付けをしてインパクト評価した結果，使用済 み携帯電話・PC に含まれる元素量をのうち, Au, Pd が高 い值を示し, $\mathrm{Cu}, \mathrm{Fe}, \mathrm{Al}, \mathrm{Pt}, \mathrm{Nd}$ が続いている TMR, 自然鉱 石中の元素濃度と比較することで評価した．最後に，各製品 に含まれる元素濃度を自然鉱石中のそれと比較した結果, 全 ての製品について $\mathrm{Au}, \mathrm{Ag}, \mathrm{Pd}$ が粗鉱よりも高い濃度を示し, $\mathrm{Pt}, \mathrm{In}, \mathrm{Cu}$ はそれらに準じて高い濃度を示していることが明 らかになった。

本研究は環境省による廃棄物処理等科学研究費補助金 (課 題番号：K1810, K1930, K2031（2006～2008)，研究代表
者 : 橋本征二, 研究課題名 : 物質ストック勘定体系の構築と その適用による廃棄物・資源管理戦略研究)により研究を行 った成果である.

文 献

1) M. Nanjo: Bulletin of the Research Institute of Mineral Dressing and Metallurgy, Tohoku University 43 No. 2 (1988) 239-251.

2) K. Halada: Press Release of National Institute for Materials Science, 11 Jan. 2008 (http://www.nims.go.jp/jpn/news/press/ pdf/press215.pdf), (as of 1/Oct/2008).

3) E. Yamasue, K. Nakajima, I. Daigo, S. Hashimoto, H. Okumura and K. N. Ishihara: Mater. Trans. 48(2007) 2353-2357.

4) Website of "PC3R Promotion Center" (http://www.pc3r.jp/index.html), as of $1 /$ Oct $/ 2008$.

5) K. Nakajima, K. Yamamoto, K. Nakano, K. Kuroda, K. Halada and T. Nagasaka: J. Life Cycle Assessment, Japan 2 (2006) $341-346$.

6) M. Oguchi, T. Kameya, T. Tasaki, N. Tamai and N. Tanigawa: J. Japan Society of Waste Management Experts 17 (2006) 5060.

7) T. Tasaki, M. Oguchi, T. Kameya and K. Urano: J. Japan Society of Waste Management Experts 12(2001) 49-58.

8) I. Daigo, D. Fujimaki, Y. Matsuno and Y. Adachi: Tetsu-toHagane 91 (2005) 171-178.

9) Japan Electronics and Information Technology Industries Association (JEITA): Industry Review: Electronics and Information Technology Industries in Japan 2006 Edition, (Public Relations Office, Strategic Planning Department, Tokyo, 2006).

10) Report by Japan Electronics and Information Technology Industries Association (JEITA): (http://www.meti.go.jp/report/ downloadfiles/g10828fj.pdf), (as of 1/Oct/2008).

11) K. Sumio: Monthly Report of Institute for Posts and Telecommunications Policy (IPTP) 15 No. 10 (2002) 67-79.

12) Website of Japan Electronics and Information Technology Industries Association: (http://www.jeita.or.jp/japanese/), (as of $1 /$ Oct/2008).

13) Ministry of Economy, Trade and Industry: Indices of Industrial Production, (http://www.meti.go.jp / statistics / tyo / seidou / index.html), (as of 1/Oct/2008).

14) Ministry of Internal Affairs and Communications: Information and Communications Statistics Database, http://www.johotsusintokei.soumu.go.jp/, (as of 1/Oct/2008).

15) M. Nisida, R. Agawa and T. Araki: Annual Journal of Eng, Ehime Univ, 5(2006) 65-73.

16) Ministry of Economy, Trade and Industry: 4th Document of Working group of 6th Basic Policy Directions by Global Environmental Subcommittee, Environmental Committee, Industrial Structure Council, (2007), (http://www.meti.go.jp/policy/ recycle/main/admin info/committee/j.html\#6).

17) K. Nakano, K. Nakajima, S. Miyabe, Y. Wada and T. Nagasaka: Kankyo Kanri 42 No. 11 (2006) 49-62.

18) Website of Mobile Recycle Network: http: // www. mobilerecycle.net/index.html, (as of 1/Oct/2008).

19) Japan Oil, Gas and Metals National Corporation: Materials Flow 2005, (Metals Strategy Department, Metals Strategy \& Exploration Unit, Tokyo, 2005).

20) K. Halada: Report of Joint Symposium by The Iron and Steel Institute of Japan and The Japan Institute of Metals, (2005) pp. 21-28.

21) E. Yamasue, H. Okumura and K. N. Ishihara: IEEJ Trans. EIS $128(2008) 6-10$. 